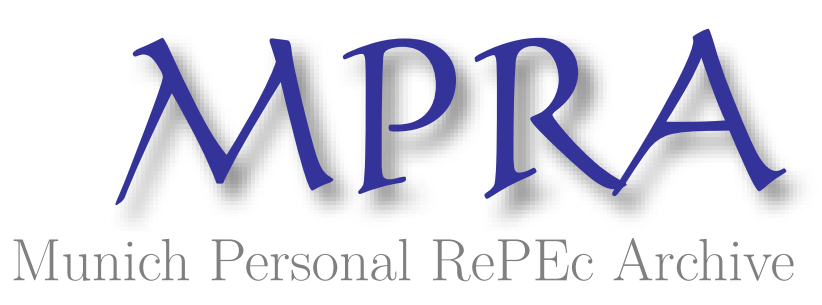

\title{
Inclusive Growth Strategies for Pakistan: Myth or Reality for Policymakers!
}

Syed Muhammad, Atif and Sardar, Mohazzam

7 July 2012

Online at https://mpra.ub.uni-muenchen.de/41376/

MPRA Paper No. 41376, posted 17 Sep 2012 13:31 UTC 
Inclusive Growth Strategies for Pakistan - Myth or Reality for Policymakers!

Sardar Mohazzam

Fulbright PhD Scholar, University of Delaware USA

Assistant Professor, Department of Government and Public Policy

National Defence University, sector E-9, Islamabad Pakistan.

mohazzam@udel.edu

Syed M. Atif Bukhari

HEC PhD Scholar

Department of Economics

University of Sydney

NSW, Australia

sati1640@uni.sydney.edu.au 


\begin{abstract}
The mantra of inclusive growth is taking over the public policy debates addressing poverty alleviation and sustained development in the developing world. In order to reduce poverty substantially, rapid pace of growth is not only necessary, but it should be sustainable in the long run and broad-based across sectors, nonetheless, inclusive of country's labour force at large. Poverty and growth were much discussed and analysed in separation by policymakers in the previous decades. Inclusive growth strategy is an integration of these two strands of analyses implying relationship between the macro and micro determinants of growth.

This paper examines the nature of relationship between the macroeconomic and social-development indicators by using a Multiple Regression Framework and Vector Auto Regression Model, as proposed by TodaYamamoto, is used to determine the direction of causality between the key macroeconomic variables of Pakistan over the period of 1997-98s to 200910. The paper critically examines Inclusive growth paradigm - for market led growth, and suggests its weaknesses which can be addressed through review of the pro-poor goals of economic policy of Post Washington Consensus (PWC). Finally, the paper urges to explore the myths and realities of inclusive growth strategies for policymakers in Pakistan to identify and prioritize the Pakistan specific constraints i.e. Low spending on health and education, promote growth in agriculture and rural development for sustained and inclusive growth.
\end{abstract}

\title{
Introduction
}

The mantra of inclusive growth is taking over the public policy debates addressing poverty alleviation and sustained development in the developing world. In the last decade, the Asian countries especially China and India have maintained a rapid and sustainable economic growth. ${ }^{1}$ The double digit growth of these elephant economies on one hand surprised the world with overall increase in the GDP, and per capita income, but on the other hand there has been a persistent negative impact on the income distribution. ${ }^{2}$ Poverty and growth which is much discussed and analyzed in separation by policymakers before and somewhat after Washington Consensus. The policy-makers have been once again challenged to gear the public policies towards a growth which is market led in nature, broad based in terms of

\footnotetext{
${ }^{1}$ Ghosh, J. (2010). "Poverty reduction in China and India: Policy implications of recent trend". DESA Working Paper No. 92

2 Ali, I. (2007). "Inequality and the Imperative for Inclusive Growth in Asia”. Asian Development Review, 24(2), pp. 1-16
} 
sectors, and inclusive of majority of labour force of the country. The desired growth strategy should not only foster the private sector but should also protect the vulnerable segment of the society.

Pakistan has a growth rate of $4.1 \%$ in $2009-10$ after turbulence of economic growth of two years. ${ }^{3}$ From the experience of Pakistan and other developing countries, it can be inferred that "period of high economic growth occurred at the expense of macroeconomic stability, but did not produced the desired outcomes with regards to poverty reduction in a sustainable manner." the dividend of the growth is accessible to large segment of the population? How policymakers can stimulate the markets led growth and also protect the vulnerable segment of the society in Pakistan.

This paper critically examines different growth paradigm offered to the developing countries by developed countries and its affiliated agencies and financial institutions. The preWashington Consensus economic policies and post-Washington Consensus pro-poor growth policies have been compared and contrasted to conclude the weakness of Inclusive growth paradigm and suggests that how it weaknesses can be addressed through review of the propoor goals of Post Washington Consensus (PWC).

Data from 1997-98 to 2009-10 have been regressed to observe the existing trends of pro-poor growth mechanism in Pakistan. An index for social development has been devised, based on health, education, governance and demographical indicators, to examine the establishment of effective human capital, which in turn leads to labor-inclusive pro-poor growth. The study

\footnotetext{
${ }^{3}$ Pakistan, Govt. of, (2010). “Economic Survey of Pakistan 2009-10". Ministry of Finance, pg. 129 After a high growth rate of 6.8 percent in 2006-07, Pakistan has experienced a declining rate of economic growth, during 2007-08 and 2008-09 (3.7\% and 1.2\% respectively). However, there has been an increase to 4.1 percent in 2009-10. As may be seen, the growth rate declined, given the international economic crisis during 2008-09 - although it was not negative as in case of some other countries."

${ }^{4}$ Ibid pg.132
} 
applies Modified WALD test, as proposed by Toda and Yamamoto (1995), on the Vector Autoregression Model designed in subsequent sections, estimated through seemingly Unrelated Regression analysis. Existence of a unidirectional causal relationship from economic growth to social development has been examined, which satiates the hypothesis of deliverance of inclusive growth by producing highly-skilled, healthy and effective labour force.

Finally, the paper also suggested a set of strategies for policymakers in Pakistan to identify and prioritize the Pakistan specific constraints to sustained and inclusive growth.

\section{Review of Literature: Historical Perspective}

It was in the late 1950s and early 1970s that the growth theories were dominated by the influential work of Kuznets (1955) and Robert Solow (1956) growth models which depicted the relationship between economic growth, inequality and poverty. The discovery of Kuznets' U shaped relationship between income inequality and economic growth in poor countries suggested that economic growth will lead to greater income inequalities, followed by decrease in this inequality provided economy continued to grow; for this continued economic growth countries had to shift from agriculture to industrial sector as there is a little variation in agricultural income as compared to industrial income. According to the framework of Convergence explained by Solow Growth Model, the developing economies contain a tendency to converge to developed economies by maintaining higher levels of growth, forced through equalization of marginal returns of factors of production between developing and developed economies, as the country progresses. Subsequently, Government and International Financial Institutions under this context of "big push" formulated policies of development for infrastructure and capital building projects in the developing countries.

By late 1970s and 1980s, the policy prescription from these models were realized as false 
hope, as neither these poor countries converged with developed countries, and nor income inequality reduced.

With the displacement of Keynesianism and the rise of monetarism and new classical economics, development theory shifted towards the so called phenomena of trickle down proposition. The proponent of "free market" policies this time offered this paradigm for poverty alleviation and better income distribution with strong argument that government intervention was reason of failure. Washington Consensus (WC) type economic policies were prescribed to "operationalize" the trickle down proposition. Dani Roderick explains WC policies as "“Stabilize, Privatize, and Liberalize" became the mantra of a generation of technocrats who cut their teeth in the developing world and of the political leaders they counselled."5 By early 1990s, the prescribed policies were immensely criticised by all spheres of life and International financial institutions were once again assigned to provide policies to deal with the problem of inequality and poverty reduction.

Millennium Development Goals (MDGs) ${ }^{6}$ were the new shift from the Washington Consensus type economic policies, and emerged as pro-poor alternative. However, as we are reaching close to the timeline to achieve the goals set by MDGs, and there is another apparent failure. "The scale of the task of achieving the Millennium Development Goals (MDGs) is daunting. The region is home to more than 900 million poor comprising more than two-thirds of the world's population in extreme poverty."7 (ADB 2010)

In late 1990s, debates about growth and inequalities tended to focus on the concept of propoor growth. The earlier notion of poverty reduction and redistribution as a by-product of

\footnotetext{
${ }^{5}$ Roderick, D. (2006). “Good Bye Washington Consensus, Hello Washington Confusion?”. Cambridge: Haravard University Press.

${ }^{6}$ U. N. (2011). "Millennium Development Goals Report-2011", Available at: http://www.un.org/millenniumgoals/11 MDG\%20Report EN.pdf, Accessed on: 17/10/2011.

${ }^{7}$ A.D.B. (2011), “Asian Development Bank Annual Report 2010”, Vol. 1, Available at: http://www.adb.org/documents/reports/annual report/2010/adb-ar2010-v1.pdf, Accessed on: 13/10/2011, pg. 16
} 
growth and macroeconomic stability was disqualified. Mainstream admitted that "Instead, poverty has to be addressed directly through a dedicated set of economic and social tools. The International Financial Institutions also had to confront claims that inequality is harmful because it induces political and economic instability and, in extreme cases, political violence and civil war." Son, 2004 and Kakwani and Pernia 2000, Baulch and McCullock, 2000, Ravallion, 2004; Ravallion and Chen, 2003, Besley and Cord, 2007, and McKinley, 2009) were presented by Nanak Kakwani and Martin Ravallion. According to Kakwani “"“pro-poor growth” means that poverty falls more than it would have if all incomes had grown at the same rate." 9 This definition prioritizes the concept of relative improvement in the poor's condition. It advocates the growth that can promote equity, so the criteria for selection of economic policies will be equity; hence all those policies which promote equity are "pro-poor". According to Ravallion “"spro-poor growth" is growth that reduces poverty." ${ }^{10}$ His definition is in absolute term, which focuses on absolute improvement of living standard of poor, without considering inequality. In this case equity has instrumental value, and it is a non-perverse type of growth. ${ }^{11}$ So in this case equity will be applied if it can enhance the impact of economic policies which target poverty alleviation - as in case of China where growth lead to decrease in the poverty but not to inequality. Both these definitions over time seems similar as both tended to reach on an agreement to reduce the poverty at the maximum level. "And for this goal, they have tended to agree that both faster growth (implying absolute improvements) and greater equity (implying relative Improvements) should be priorities" (MacKinely, 2009, pg. 6). In specifically everyone gains from faster growth, there may be some loss in case of equity promoting growth policies which may cause some political tension and partly

\footnotetext{
${ }^{8}$ Saad-Filho, A. (2010). "Growth, Poverty and Inequality: From Washington Consensus to Inclusive growth". DESA Working Paper No. 100, pg. 8

${ }^{9}$ Ravallion, M. (2004). "Pro-Poor Growth: A Primer". Development Research Group: World Bank. pg. 2

${ }^{10}$ Ibid pg. 2

${ }^{11}$ Ibid. 8, Saad-Filho, A. (2010). Pp.9
} 
economic efficiency loss. So the shift from goal of reducing poverty through the principle of equity has been shifted to principle of growth as logical consequence of this discussion.

With the departure of the equity from these debates and rise of definition of absolute pro-poor growth, World Bank and Commission on Growth and Development (CGD) ${ }^{12}$ - Group, described the growth and social development in the following way:

"Growth is not an end in itself. But it makes it possible to achieve other important objectives of individuals and societies. It can spare people en masse from poverty and drudgery. Nothing else ever has. It also creates the resources to support health care, education, and the other Millennium Development Goals to which the world has committed itself. In short, we take the view that growth is a necessary, if not sufficient, condition for broader development, enlarging the scope for individuals to be productive and creative."13

The CGD Report 2008, on one hand explains growth in terms of competitive pressure and on the other hand re-iterates the role of government. It explains to address the pressure of competitiveness; the government should liberate the product markets, and remove entry barriers for more productive firms. Surprisingly, it indicated that government should intervene into the labour market for the quick creation of jobs and for worker mobility within the labour market to fill the job. ${ }^{14}$ Along with the public sector expenditure on the development of Infrastructure and creation of physical and human capital this would crowdin private investment. World Bank report "What is Inclusive growth?" (World Bank 2009) and CGD Report 2008 mentioned different strategies that governments should adopt for the

\footnotetext{
${ }^{12}$ The Commission of Growth and Development is an autonomous body of policy makers, businessmen and scholars supported by World Bank and other Multinational giants and Governments.

${ }^{13}$ Commission of Growth and Development, "The Growth Report: Strategies for Sustained Growth and Inclusive Development Report". Avaiable at: cgd.s3.amazonaws.com/GrowthReportComplete.pdf, Accessed on: 04/10/2011, pg. 1

14 Ibdi pg. 6
} 
sustained and steady growth along with commitment of World Bank itself with "Growth Diagnostic" approach.

\section{Inclusive Growth: Tinkering for Poverty Reduction and Growth}

In late 2000s, World Bank and its affiliates supported the development Inclusive growth paradigm. The Inclusive growth paradigm emerged with the convergence of debates on Propoor growth (differentiation between pro-poor and inclusive growth, the former approach focuses on welfare of the poor, and the later focuses on majority of labour force, poor and middle class and is in line absolute definition of pro-poor growth), and development of new (neo-classical) growth framework by World Bank. Inclusive growth paradigm focuses on the importance of growth for the reduction of poverty, further, it explains that the achievement of these outcomes are possible with a combinations of broad range of policies which can be selected through the "growth diagnostics.",

Inclusive growth strategy is an integration of two strands of analyses i.e. Poverty and growth, which implies relationship between the macro and micro determinants of growth. ${ }^{16}$ The paradigm of Inclusive growth can be defined as to reduce poverty substantially, rapid pace of growth is not only necessary, but it should be sustainable in the long run and broad-based across sectors, nonetheless, inclusive of country’s labour force at large. ${ }^{17}$ "[This] broad based and inclusive growth does not imply a return to Government-sponsored industrial policies, but instead puts the emphasis on policies that remove constraints to growth and create a level playing field for investment." 18

\footnotetext{
${ }^{15}$ Ibid. 8, Saad-Filho, A. (2010). Pp. 13

${ }^{16}$ Elena, I. and Susanna, L. (2009). "What is Inclusive Growth?". Available at: http://siteresources.worldbank.org/INTDEBTDEPT/Resources/4689801218567884549/WhatIsInclusiveGrowth20081230.pdf, Accessed on: 04/10/2011

17 Ibid pg.1

18 Ibid. pg.2
} 
Inclusive growth paradigm is has two distinct feature, first as it is based on the successful growth experience of the development countries around the world. Second, it is not only identical with post-Washington Consensus (see fig. 1) but also have similarity of "big push" model led by government for the development for growth - which demands "public sector investment in infrastructure and physical and human capital, including roads, ports, airports, power, telecommunications, health and education especially for girls." ${ }^{\prime 19}$

There are certain limitations of Inclusive growth paradigm. With the premise that economic growth is the sole driver of poverty reduction, growth has inbuilt "process of creative destruction" ${ }^{20}$ and it can create poverty. Growth brings with itself technological can alter in property and user rights. The transformation in labour market can lead to unemployment and increase in poverty. If the growth is not sustained and there is insufficient growth in GDP as in case of Pakistan, this may lead to decline in welfare of large population. It contradicts with the claims of the "absolute definition" of pro-poor growth.

Fig .1 Sources: (Alfredo Saad-Filho, 2010 pg. 14)

\begin{tabular}{|c|c|c|}
\hline Original Washington Consensus & $\begin{array}{c}\text { Post-Washington Consensus } \\
\text { (Original WC plus) }\end{array}$ & Inclusive Growth \\
\hline $\begin{array}{l}\text { Secure property rights } \\
\text { Deregulation } \\
\text { Fiscal Discipline } \\
\text { Tax reform } \\
\text { Privatization } \\
\text { Reorientation of public expenditure } \\
\text { Financial liberalization } \\
\text { Trade liberalization } \\
\text { Openness to FDI } \\
\text { Unified and competitive exchange } \\
\text { rates }\end{array}$ & $\begin{array}{l}\text { Anti-corruption } \\
\text { Corporate governance } \\
\text { Independent central bank and IT } \\
\text { Financial codes and standards } \\
\text { Flexible labour markets } \\
\text { WTO agreements } \\
\text { "Prudent" capital account opening } \\
\text { Non-Intermediate exchange rate } \\
\text { regimes } \\
\text { Social safety nets } \\
\text { Targeted poverty reduction }\end{array}$ & $\begin{array}{l}\text { Competitive Environment } \\
\text { Government commitment to } \\
\text { growth } \\
\text { "Good policies" } \\
\text { Labour market deregulation } \\
\text { Employment and productivity } \\
\text { growth } \\
\text { International integration } \\
\text { Exchange rate management } \\
\text { "Prudent" capital account opening } \\
\text { Social safety nets }\end{array}$ \\
\hline
\end{tabular}

\footnotetext{
19 Ibid. 8, Saad-Filho, A. (2010), pg.12

${ }^{20}$ Schumpeter, J. A. (1975). "Capitalism, Socialism and Democeacy, Schumpeter", Chapter VIII. NY: Harper and Row Pub.
} 


\section{METHODOLOGY AND DATA ANALYSIS}

\section{DATA}

The study examines time series data of Per Capita Income (at current \$US) and a newly designed index for measuring social development for Pakistan over the time period of 199798 to 2009-10. The time period, restrained by data availability, has specifically been selected to include the economic cyclical variation of downturn after 1998 Nuclear tests, followed by boom after the alleged inclusion in War on Terror in post-9/11 scenario, inflated by highest economic growth levels achieved during 2004- $06^{21}$ and the sudden downturn of economy in 2007-08 amid the security threats and governance issues, coupled by the Global Financial Crisis of $2008^{22}$. The data for variables in Index for Social Development (ISD) and Per Capita Income (PCI) has been taken from Economic Survey of Pakistan 2010-11 23 and World Development Indicators of the World Bank.

\section{INDICATORS}

Historically, economic growth has largely been discussed in relationship with the Gross Domestic Product (GDP) ${ }^{24}$. The per-capita income, however, maintains the effectiveness of GDP by considering the impact of population and its growth over time. Moreover, the percapita income in current US dollar is an approximate representative of true nature of economy by taking into consideration the varying trends of exogenous impact of foreign exchange, instead of a measure in constant US dollar (2000) this is irrespective of any trends

\footnotetext{
${ }^{21}$ Pakistan, Government of (2007). "Pakistan Economic Survey 2006-07". Ministry of Finance, Chapters-1; Growth and Investment

${ }^{22}$ Saleem, F. (2009). "Pakistan and the Global Financial Crisis, Centre for Research and Security Studies". Available at: http://www.boell.de/downloads/economysocial/Pakistan Report on Economics 2 Jan2009.pdf,Accessed on: 24/10/2011

${ }^{23}$ Pakistan, Government of, (2011). "Pakistan Economic Survey 2010-11". Ministry of Finance, Chapters 10, 11, 12 and 13.

${ }^{24}$ Barro, R. J. \& Sala-i-Martin, X. (2003). “Economic Growth”, $2^{\text {nd }}$ Edition, Chapter-I, Cambridge: MIT Press, pp. 23-73
} 
in the global economy. Therefore, the study deals per-capita income in current US dollar as a proxy for Economic Growth.

Furthermore, based on literature review ${ }^{25}$, the index for social development is devised on four major indicators; Health, Education, Governance and Demographics, further subdivided into 21 variables.

\section{Health Indicator}

It includes the variables; Crude Birth Rate (per 1000 people), Crude Death Rate (per 1000 people), Life Expectancy at Birth (years), Infant Mortality Rate (per 1000 live births), Fertility Rate (births per woman) and Population per Hospital Bed. Other variables explaining the nature of nourishment of population, such as per capita calories and protein consumption could not be included in the indicator due to insufficient data availability.

\section{Education Indicator}

In a society where literal definition of literacy includes being able to write one's name and reading the newspaper, the education indicator focuses on lower level education by including Primary, Middle and Secondary stage enrolment of pupils, and number of teachers in Primary, Middle and Secondary stage, and literacy rate. The Pupil/Teacher ratio has been calculated by division of cumulative pupils and teachers, which gives an overall estimate of the lower level education in Pakistan, excluding the University enrolment and teachers.

\section{Demographics}

This indicator focuses on the demographical aspects by examining the nature of urbanization, level of employment and population statistics. It includes Population Density (people per sq.

\footnotetext{
${ }^{25}$ Szirmai, A. (2005). "The Dynamics of Socio-Economic Development: An Introduction", Chapter 5-7. UK: Cambridge University Press, pp. 141-248; and

Mazumdar, K. (1996). “An Analysis of Causal Flow between Social Development and Economic Growth: The Social Development Index". Americal Journal of Economics and Sociology, 55(3), pp.361-383; and Khan, H. (1986). "Socio Economic Development of ASEAN: An International Perspective (Chapter-2)". Singapore: Chopman Publisher, pp 13-28
} 
kilometer of land area), Total Population, Total Labor Force, Labor Force Participation Rate, Unemployment (percentage of total labor force).

\section{Governance Indicator}

This indicator includes different modes of public spending, with focus on the fundamental needs of people. Public spending on health, on education and military expenditure, as percentage of GDP, aides in determining the public priorities, meaning thereby the governments focus on provision of social amenities.

The intuitive explanation of variables explained above, delineates a positive relationship between individual variable and economic growth. As it can be addressed that an improved health index, owing to the better provision of health services, can be examined by periodic movement of the variables in this index. By looking into the raw data, it is viewed that crude birth rate and crude death rate are declining over time, meaning thereby that the prevailing problem of significantly high population growth may eventually be controlled. Likewise the increase in life expectancy at birth, and hospital beds, and decrease in infant mortality also portray an improved health sector. But these variables individually can not account for a significant impact on economic growth, whereas an overall improved health index is supposed to be augmenting the economic growth process by means of effective human capital $^{26}$.

However, this generalization excludes the expenditure on military and defense, as apparently the defense expenditure bears the opportunity cost of expenditure on other pro-poor sectors. The defense expenditure may be considered as a non-development expenditure due to its incapability of directly impacting the economic growth of any economy. The portion of economic growth owing to the improvement in health index, can thereby be regarded as the

\footnotetext{
${ }^{26}$ Ranis, G. (2004). “Human Development and Economic Growth”. Centre Discussion Paper No. 887, USA: Yale University.
} 
pro-poor growth because it is eventually increasing the efficiency of labor, and hence an improved marginal product, which satiates the Solow's concept of convergence through equalization of marginal product of factors of production ${ }^{27}$.

Based on the same footings, an explanation for the education sector can be attained. An intuitive description of improved education index leads to an improved employment scenario by producing more literate and skilled labor force, which again follows the same modeling of Endogenous Growth Theory as discussed earlier. However, unlike the health index, education index focuses on other factors of production too. Highly skilled labor produced through increased literacy eventually leads to induction of effective physical capital and structural transformation of a more capital intensive economy. Alongside, the education index produces improved entrepreneurial scenario for the economy. Hence, the concept of convergence again comes into effect if an improved education index can be established for a developing economy. Lastly, the demographics index deals with the dynamics of population, and direct inductions and deductions in the effective labor force in the economy. The apparent incline in the unemployment statistics overtime is alarming for policy makers. The dynamics of landmark Philip's Curve have been overturned in developing economies such as Pakistan, where inflation and unemployment are presenting a positive relationship over time ${ }^{28}$, against the traditional negative relationship as explained by the Philip's curve ${ }^{29}$.

\section{INDEX FOR SOCIAL DEVELOPMENT}

The Index for Social Development is constructed, by using the statistical technique for data reduction, called Principal Component Analysis, applied on 21 variables explained above to formulate the combination of principal components explaining at least 70 percent of the

\footnotetext{
${ }^{27}$ Ibid 24. Barro, J. R., and Salah-i-Martin, X. (2003)

${ }^{28}$ Ibid 23, Economic Survey of Pakistan 2010-11. Chapter 7: Inflation, and Chapter-12: Population, Labor Force and Employment

${ }^{29}$ Dufour, J., Khalaf, L. and Kichian, M. (2005). “Inflation Dynamics and the New Keynesian Phillips Curve: An Identification Robust Econometric Analysis". Bank of Canada Working Paper 2005-27
} 
variation in data. The Principal Component Analysis (commonly known as PCA) is one of the simplest forms of Applied Multivariate Analysis, that takes p-variables $\left(\mathrm{X}_{1}, \mathrm{X}_{2}, \ldots, \mathrm{X}_{\mathrm{p}}\right)$ and finds combinations on standardized form of these variables to produce uncorrelated indexes $\left(Z_{1}, Z_{2}, \ldots Z_{p}\right)$, known as the principal components, ordered according to weight of respective principal component (known as Eigen Values), whereby Eigen values explicate the percentage variance of whole data explained by respective principal component ${ }^{30}$. Standardization of the variables has been formed based on the methodology explained by Mazumdar (1996) ${ }^{31}$ :

$$
Y_{i j}=\frac{X_{i j}-X_{i \min }}{X_{i \max }-Y_{i \min }}
$$

Where $\mathrm{X}_{i \min }$ and $\mathrm{X}_{i \max }$ are the minimum and maximum values of $i^{\text {th }}$ series, respectively.

\section{METHODOLOGY}

The paper discusses causal relationship between economic growth and social development by examining selective indicators of health, education, governance and demographics of Pakistan. The core steps include formulation of functional form of the model, based on the indicators discussed above, followed by a multiple linear regression, explaining the impact of individual indicator on economic growth. This helps in formulating the grounds for estimating the causal relationship between both indices, based on which the study proceeds by examining of the order of integration of individual series, and in the final step, testing the true direction of causality by applying Modified WALD (MWALD) test as proposed by Toda

\footnotetext{
30 Manly, B. F. J. (2005). "Multivariate Statistical Methods: A Primer". $3^{\text {rd }}$ Edition, Chapter-6, New York: Chapman and Hall/CRC, pp. 75-90

31 Ibid. 25, Mazumdar, K. (1996)
} 
and Yamamoto $(1995)^{32}$, on the Vector Autoregression (VAR) Model estimated through Seemingly Unrelated Regression (SUR) ${ }^{33}$.

\section{Functional Form and Multiple Linear Regression}

Based on the above discussion, the functional form of model is devised as follows:

$$
P C I_{t}=f\left(H_{t}, E_{t}, G_{t}, D_{t}\right)
$$

Where $\mathrm{PCI}_{\mathrm{t}}$ is the per-capita income (proxy for economic growth), $\mathrm{H}_{\mathrm{t}}$ explains the health indicator, $E_{t}$ relates to the education indicator, $G_{t}$ measures the index for governance and $D_{t}$ is the indicator of demographical conditions of the economy, where education index contains cumulative teachers per 1000 cumulative students.

The indices for each variable are designed by using the Principal Component Analysis and the multiple linear regression model is framed as follows:

$$
P C I_{t}=\varphi_{0}+\varphi_{1} H_{t}+\varphi_{2} E_{t}+\varphi_{3} G_{t}+\varphi_{4} D_{t}+u_{t}
$$

Where $\varphi_{i}(i=1,2,3$ and 4$)$, explains the average change in PCI caused by average change in the $i^{\text {th }}$ variable over the unitary time movement, holding all else constant, and $u_{t}$, the error term, explains the change in dependent variable by any regressing factors other than those included in the model. The estimated model is given in equation (3):

$$
\begin{aligned}
& \widehat{P C} I_{t}=-\mathbf{1 0 0 . 1 6 3 2}+\mathbf{1 . 4 2 7}\left(H_{t}\right)+\mathbf{3 . 9 7 1}\left(E_{t}\right)-\mathbf{1 . 1 8 2}\left(G_{t}\right)+\mathbf{1 . 7 0 5}\left(D_{t}\right) \\
& \mathrm{SE}
\end{aligned}
$$

The estimated equation elaborates that per-capita income is positively associated with the health index, education index and demographics index, and inversely related with the governance index which mainly deals with public expenditure on health, education and

\footnotetext{
32 Toda H.Y. and Yamamoto, T. (1995). "Statistical inference in vector autoregressions with possibly integrated process". Journal of Econometrics, 66, 225-250

${ }^{33}$ Gujarati, D. N. (2002). "Basic Econometrics”. Fourth Edition, Chapter-21\&22. New York: McGraw Hill, pp.792868
} 
defense. The governance index has significantly emerged to be an important factor in the policy making for Pakistan. The interesting point that emerges here is the negative relationship between economic growth and the governance index. It has been observed that over the period of time, public expenditure on military and defense has superseded the expenditure on other sectors, or according to this study specifically education and health sector $^{34}$. Intuitively, it can be deduced that the excessive overburdening of government by defense sector, has reduced its competencies for excelling in other sectors. Or in other words, the government's focus on its defense, which can not be considered as an element directly impacting the economic growth, is leading to its poor performance in other sectors of the economy, which is eventually leading to lower economic growth in other sectors, which is compatible to our assumption in variable explanation about inclusion of military expenditure in the model.

The apparent situation in estimated equation in (3), focuses on education sector, by relating that a unitary increase in the educational index, will lead to a great than unitary change in economic growth, thereby laying insistence on priority in this sector. However, these results do not portray a vivid picture of the nature of causal relationship, i.e. from the above model it can not be deduced whether the causal relationship flows from these four indicators to the economic growth.

Amid this problem of determination in the direction of causality, the Index for Social Development is formed by using PCA, based on the variables discussed above, so that the functional form for Vector Autoregressive Model is given as:

$$
P C I_{t}=f\left(I S D_{t}\right)
$$

\footnotetext{
34 Ibid 23, Pakistan Economic Survey 2010-11. Chapter-1, Growth and Investment, Chapter-4: Fiscal Development, Chapter-11: Health
} 
Where PCI is the real per capita income in current US dollar and ISD is the Index for Social Development devised in the previous section.

\section{Order of Integration}

The order of integration for respective series is determined by using Augmented-Dickey Fuller test ${ }^{35}$. Assuming 5 percent level of significance and null hypothesis of absence of unit root, exhibits the results in table-1, for both the series. It
Table-1

\begin{tabular}{|l|c|c|c|}
\hline \multicolumn{4}{|c|}{ AUGMENTED DICKEY FULLER TEST } \\
\hline & Per Capita Income \\
\hline At level & 0.683 & 0.985 & $\begin{array}{c}\text { Accept } \\
\mathrm{H}_{0}\end{array}$ \\
\hline At $1^{\text {st }}$ difference & -2.327 & 0.181 & $\begin{array}{c}\text { Accept } \\
\mathrm{H}_{0}\end{array}$ \\
\hline At $2^{\text {nd }}$ difference & -3.215 & 0.04 & Reject $\mathrm{H}_{0}$ \\
\hline \multicolumn{4}{|c|}{} \\
\hline
\end{tabular}

\begin{tabular}{|l|c|c|c|}
\hline \multicolumn{3}{|c|}{ Index for Social Development } \\
\hline At level & t-value & p-value & Inference \\
\hline At $1^{\text {st }}$ difference & -1.45 & 0.519 & $\begin{array}{c}\text { Accept } \\
\mathrm{H}_{0}\end{array}$ \\
\hline At $2^{\text {nd }}$ difference & -3.132 & 0.054 & $\begin{array}{c}\text { Accept } \\
\mathrm{H}_{0}\end{array}$ \\
\hline
\end{tabular}

is observed that both the series are augmented at order-2, i.e. I(2)

\section{Toda-Yamamoto Augmented Granger Causality Test}

This study uses the Modified WALD Test (MWALD) as proposed by Toda and Yamamoto $(1995)^{36}$. Toda and Yamamoto (1995) introduced a relatively simpler and straightforward causality test involving the WALD test based on augmented VAR modeling that asymptotically has a chi-square distribution irrespective of the order of integration or cointegration properties of the variables. The test is valid regardless of whether the series is $\mathrm{I}(0), \mathrm{I}(1)$ or $\mathrm{I}(2)$, cointegrated or noncointegrated. The test artificially augments the correct VAR order $(k)$ by the maximum order of integration $\left(d_{\max }\right)$. Then $k+d_{\max }$ th order of VAR is estimated and the coefficients of the last lagged $d_{\max }$ are ignored ${ }^{37}$. This validates that

\footnotetext{
35 Ibid 33. Gujarati, D. N. (2002)

${ }^{36}$ Ibid 32. Toda H.Y. and Yamamoto, T. (1995)

${ }^{37}$ Wolde-Rufael, Y. (2008). Energy consumption and economic growth: the experience of African countries revisited. Energy Economics, 31, 217-224.
} 
standard asymptotic distribution is prevalent in the test statistic for Granger Causality test and valid inferences could be made.

The study follows the model proposed by Wolde-Rufael $(2008)^{38}$ :

$$
\begin{aligned}
& P C I_{t}=\alpha_{0}+\sum_{i=1}^{k} \alpha_{1 i} P C I_{t-i}+\sum_{j=k+1}^{d \max } \alpha_{2 j} P C I_{t-j}+\sum_{i=1}^{k} \beta_{1 i} I S D_{t-i}+\sum_{j=k+1}^{d \max } \beta_{2 j} I S D_{t-j}+\varepsilon_{1 t} \\
& S D I_{t}=\gamma_{0}+\sum_{i=1}^{k} \gamma_{1 i} I S D_{t-i}+\sum_{j=k+1}^{d \max } \gamma_{2 j} I S D_{t-j}+\sum_{i=1}^{k} \delta_{1 i} P C I_{t-i}+\sum_{j=k+1}^{d \max } \delta_{2 j} P C I_{t-j}+\varepsilon_{2 t}
\end{aligned}
$$

The above system of equations is estimated by Seemingly Unrelated Regression (SUR) method. For equation (5), ISD Granger Causes PCI if $\mathrm{H}_{0}: \beta_{1 i}=0$ is rejected against $\mathrm{H}_{\mathrm{A}}$ : at least one $\beta_{1 i} \neq 0$ and for equation (6), PCI Granger Causes ISD if $\mathrm{H}_{0}: \delta_{1 i}=0$ is rejected against $\mathrm{H}_{\mathrm{A}}$ : at least one $\delta_{1 i} \neq 0$ (where $\mathrm{i}=1, \ldots, \mathrm{k}$ and the parameters of $\mathrm{i}=\mathrm{k}+1, \ldots, \mathrm{d}_{\max }$ are ignored). Bidirectional causality exists if both the null hypotheses are rejected against the respective alternative hypotheses. And there will be no causality if both the null hypotheses are accepted.

According to the Akaike and Schwarz Information criteria the optimal log-length for the model is 1 (i.e. $\mathrm{k}=1$ ) and the highest order of integration has been determined at 2 (i.e $\mathrm{d}_{\max }=2$, and $\mathrm{k}+\mathrm{d}_{\max }=3$ ), thereby formulating the estimated model as follows:

$$
\begin{aligned}
& P C I_{t}=224.53+0.862 * S D I_{(t-1)}+0.513 * S D I_{(t-2)}-1.296 * S D I_{(t-3)}+1.161 * P C I_{(t-1)}- \\
& 0.277 * P C I_{(t-2)}-0.266 * P C I_{(t-3)} \\
& S D I_{t}=372.331-0.462 * S D I_{(t-1)}+0.002 * S D I_{(t-2)}+0.213 * S D I_{(t-3)}-0.103 * P C I_{(t-1)} \\
& +0.291 * P C I_{(t-2)}+0.282 * P C I_{(t-3)}
\end{aligned}
$$




\begin{tabular}{|c|c|c|c|c|}
\multicolumn{1}{c|}{ Table-2 } & \multicolumn{1}{c|}{} \\
\hline$(4)$ & Null Hypothesis & Chi-Sq. & p-value & Inference \\
\hline$(5)$ & ISD does not Granger Cause PCI & 1.401 & 0.237 & Accept $\mathrm{H}_{0}$ \\
\hline
\end{tabular}

The results for the Modified WALD test, as proposed by Toda and Yamamoto, suggest that there is unidirectional causality from per-capita income to the index for social development, but vicé versa is not true. In other words, there exists a unidirectional relationship from Economic Growth to the Social Development of society, and based on the past trends examined by this study, a persistent increase in the economic growth, will eventually lead to an increased social development.

It may therefore be inferred, that according to the available statistics, over the given period of time, economic growth resulted in better education by means of high literacy rates, improved strength of enrolment and teachers in lower education sector, improved health services by means of reduced death rates, controlled birth rates and increased availability of health services to the lower income group, and relatively higher opportunities of employment (as the increase in labor force supersedes the increase in unemployment rate, which means that the marginal increase in labor force through high population growth rate is being absorbed by the improved employment scenario in economy).

An overall impact of economic growth can be dealt as an increase in Inclusive growth by effectively improving the overall scenario in the market for factors of production, which includes generating effective human capital, transforming to more capital intensive techniques of production through highly skilled labor, and establishing a significant entrepreneurial sector by the comparatively more literate human capital. 


\section{Conclusion and Strategy for Pakistan}

Pakistan and its neighbors emerging Asian economies feel the positive thrust of inclusive growth, which is demanding broad based expansion of opportunities and enhancement of the capabilities at economy wide with entailment at household level. Public policy intervention should be exercised for circumstance-based disadvantaged ensuring level playing field for the empowerment of people to explore and utilize the opportunity produced by sustainable growth.

Based on the finding an interesting implication that can be drawn from results discussed in earlier sections, deals with the negativity of coefficient for governance indicator. Though, the variables included in this indicator make it a politics-free variable, by considering only public expenditure, yet the inferences that can be drawn are not really free of politics. An overall negative impact of public expenditure on education, health and defense, does not satiate the rational myths of Inclusive growth. However, if the indicator is dealt in opportunity cost terms, the inference starts making sense. Amid the security threats, inter-regional and intraregional, Pakistan has been maintaining a competitively large army, but the results of this study suggest that opportunity cost of maintaining a massive military-budget is occurring to be too high for Pakistan by exposing its effective labor, or in a broader sense, inclusive growth at stake.

Hence, an intuitive resolution is to revisit the focus of public expenditure and construct a mechanism prone to the pro-poor sector by investing more into two core sectors of the economy; health and education. Reforms related to governance, public policies and institutions which deal with economics should be addressed systematically. An active and enlightened Pakistan is needed to bind with private sector to drive growth for the happiness and prosperity that is shared among its people. 


\section{REFERENCES}

- A.D.B. (2011), “Asian Development Bank Annual Report 2010”, Vol. 1, Available at: http://www.adb.org/documents/reports/annual_report/2010/adb-ar2010-v1.pdf, Accessed on: 13/10/2011, pg. 16

- Ali, I. (2007). "Inequality and the Imperative for Inclusive Growth in Asia". Asian Development Review, 24(2), pp. 1-16

- Barro, R. J. \& Sala-i-Martin, X. (2003). “Economic Growth”, $2^{\text {nd }}$ Edition, Chapter-I, Cambridge: MIT Press, pp. 23-73

- Baulch, B. \& McCulloch, N. (2000). "Simulating the Impact of Policy upon Chronic and Transitory Poverty in Rural Pakistan". Econometrics, (43). EconWPA.

- Besley, T. and Cord, L. (2006). "Delivering on the Promise of Pro-poor Growth: Insights and Lessons from Country Experiences". Basingstoke: Palgrave Macmillan

- Commission of Growth and Development, "The Growth Report: Strategies for Sustained Growth and Inclusive Development Report". Avaiable at: cgd.s3.amazonaws.com/GrowthReportComplete.pdf, Accessed on: 04/10/2011,pg. 1

- Dufour, J., Khalaf, L. and Kichian, M. (2005). "Inflation Dynamics and the New Keynesian Phillips Curve: An Identification Robust Econometric Analysis". Bank of Canada Working Paper 2005-27

- Elena, I. and Susanna, L. (2009). "What is Inclusive Growth?”. Available at: http://siteresources.worldbank.org/INTDEBTDEPT/Resources/4689801218567884549/WhatIsInclusiveGrowth20081230.pdf, Accessed on: 04/10/2011

- Ghosh, J. (2010). "Poverty reduction in China and India: Policy implications of recent trend". DESA Working Paper No. 92

- Gujarati, D. N. (2002). "Basic Econometrics”. Fourth Edition, Chapter-21\&22. New York: McGraw Hill, pp.792-868 
- Kakwani, N. and E. Pernia. (2000). "What is Pro-poor growth?”, Asian Development Review, 18(1)

- Kakwani, N., Shahid K. and Hyun H. S. (2004). "Pro-Poor Growth: Concepts and Measurements with Country Case Studies”. Working Paper \#1 of the International Poverty Centre, Brasilia.

- Khan, H. (1986). "Socio Economic Development of ASEAN: An International Perspective (Chapter-2)". Singapore: Chopman Publisher, pp 13-28; and

- Manly, B. F. J. (2005). "Multivariate Statistical Methods: A Primer". $3^{\text {rd }}$ Edition, Chapter-6, New York: Chapman and Hall/CRC, pp. 75-90

- McKinely, T. (2009). Revisiting the dynamics of growth, inequality and poverty reduction. Centre for Development Policy and Research, SOAS, Discussion Paper No. $25 / 90$.

- Mazumdar, K. (1996). "An Analysis of Causal Flow between Social Development and Economic Growth: The Social Development Index". Americal Journal of Economics and Sociology, 55(3), pp.361-383; and

- Pakistan, Government of (2007). "Pakistan Economic Survey 2006-07”. Ministry of Finance.

- Pakistan, Govt. of, (2010). “Economic Survey of Pakistan 2009-10”. Ministry of Finance.

- Pakistan, Government of, (2011). "Pakistan Economic Survey 2010-11”. Ministry of Finance.

- Ranis, G. (2004). "Human Development and Economic Growth”. Centre Discussion Paper No. 887, USA: Yale University.

- Ravallion, M. (2004). "Pro-Poor Growth: A Primer". Development Research Group: World Bank. 
- Ravallion, M. \& Chen, S. (2003). "Measuring Pro-Poor Growth". Economic Letters, (78), pp. 93-99.

- Roderick, D. (2006). "Good Bye Washington Consensus, Hello Washington Confusion?". Cambridge: Haravard University Press.

- Saad-Filho, A. (2010). "Growth, Poverty and Inequality: From Washington Consensus to Inclusive growth". DESA Working Paper No. 100, pg. 8-14

- Schumpeter, J. A. (1975). "Capitalism, Socialism and Democeacy, Schumpeter", Chapter VIII. NY: Harper and Row Pub.

- Saleem, F. (2009). "Pakistan and the Global Financial Crisis, Centre for Research and Security Studies". Available at: http://www.boell.de/downloads/economysocial/ Pakistan_Report_on_Economics_2_-Jan2009.pdf,Accessed on: 24/10/2011

- Szirmai, A. (2005). "The Dynamics of Socio-Economic Development: An Introduction", Chapter 5-7. UK: Cambridge University Press, pp. 141-248; and

- Toda H.Y. and Yamamoto, T. (1995). "Statistical inference in vector autoregressions with possibly integrated process". Journal of Econometrics, 66, 225-250

- U. N. (2011). "Millennium Development Goals Report-2011", Available at: http://www.un.org/millenniumgoals/11_MDG\%20Report_EN.pdf, Accessed on: $17 / 10 / 2011$

- Wolde-Rufael, Y. (2008). Energy consumption and economic growth: the experience of African countries revisited. Energy Economics, 31, 217-224. 